\title{
SCALES, DYNAMICS AND SPATIAL PATTERNS OF FORCED INTERNAL DISPLACEMENT OF POPULATION IN THE EAST OF UKRAINE
}

\section{Maryna LOHVYNOVA}

\author{
V. N. Karazin Kharkiv National University, Ukraine \\ logvinova_mari94@ukr.net
}

\begin{abstract}
Eastern Ukraine is a region where for the first time during the time of independent Ukraine in 2014 forced internal migration of the population arose, as well as a region that accepted almost $2 / 3$ of all internally displaced persons (IDPs). The uneven concentration of IDPs in the Eastern region of Ukraine creates an excessive burden on the labor market, infrastructure, and local authorities. The purpose of the study is to identify and explain the spatio-temporal features of forced internal displacement in the East of Ukraine from 2014 to 2019. The study is based on statistics from the Ministry of Social Policy of Ukraine, Donetsk, Luhansk and Kharkiv regional state administrations. The following research methods were used in the work: mathematicalstatistical, analysis and synthesis method, generalization, description, systematization, retrospective, graphic, cartographic and cartographic modeling. The study of the dynamic aspects of IDPs in the region revealed a gradual decrease in the dynamics of the number of IDPs, which may be due to the successful integration of forced migrants into host communities, the reluctance to confirm the status of IDPs through bureaucratic procedures and periodic inspections, or with repeated displacement. Analysis of the spatial characteristics of IDPs by city, city councils and districts of the Eastern region of Ukraine allowed us to distinguish three categories of IDPs depending on their location in the region. Among them: the overwhelming majority - IDPs of retirement age, who are guided by the factor of territorial proximity, are registered in the areas closest to the demarcation line, although most of them actually live in territory beyond the control of Ukraine, and carry out periodic trips through the demarcation line; IDPs of working age, which are mainly located in cities for the purpose of employment and access to quality services; the most vulnerable and socially unprotected categories living in places of compact accommodation of IDPs, but their minority. The age structure of IDPs is considered, the predominant age group of all regions of Eastern Ukraine are pensioners. The regions with the highest share of pensioners and a large demographic burden of pensioners and IDP children on the local population are identified. In particular, in some areas of the Luhansk region, the number of IDP pensioners is almost double that of the local population of all age groups. This situation requires special attention, since an excessive concentration of IDP pensioners in these territories can lead to a deep demographic crisis.

So, the socio-geographical analysis of the spatial distribution of IDPs in the Eastern region of Ukraine shows the real extent of forced internal population displacement in the region, and the analysis of the age structure of IDPs allows one to determine the options for the impact of forced migrations on the socio-economic development of host regions and serves as an indicator of the need to adopt appropriate programs or decisions regarding the improvement of the situation of IDPs.
\end{abstract}

Key words: forced migration, internal displacement of the population, internally displaced persons (IDPs), migrants, Eastern Ukraine, military conflict, demographic burden.

DOI: https://doi.org/10.17721/2413-7154/2020.83.29-36

UDC: $911.3: 314.151 .3$

Received: May 8, 2020.

Revised: May 24, 2020.

Accepted: May 28, 2020.

\section{МАСШТАБИ, ДИНАМІКА ТА ПРОСТОРОВІ ОСОБЛИВОСТІ ВИМУШЕНОГО ВНУТРІШНЬОГО ПЕРЕМІЩЕННЯ НАСЕЛЕННЯ НА СХОДІ УКРАЇНИ \\ Марина ЛОГВИнОВА}

Харківський національний університет імені В. Н. Каразіна, Україна

logvinova_mari94@ukr.net

Анотація: Східна Україна - регіон, де вперше за часів незалежної України у 2014 р. виникли вимушені внутрішні міграції населення, а також регіон, який прийняв майже 2/3 усіх внутрішньо переміщених осіб (ВПО). Нерівномірна концентрація ВПО по території Східного регіону України створює надмірне навантаження на ринок праці, об'єкти інфраструктури, органи місцевої влади. Мета дослідження полягає у виявленні та поясненні просторово-часових особливостей вимушеного внутрішнього переміщення населення на Сході України з 2014 по 2019 рр. Дослідження базується на статистичних даних Міністерства соціальної політики України, Донецької, Луганської та Харківської обласних державних адміністрацій. У роботі використано такі методи дослідження: математико-статистичний, метод аналізу та синтезу, узагальнення, опису, систематизації, ретроспективний, графічний, картографічний та картографічного моделювання. В результаті дослідження динамічних аспектів ВПО в регіоні виявлено поступове зменшення динаміки їх чисельності, що може бути пов'язано з успішною інтеграцією вимушених мігрантів у приймаючі громади, небажанням підтверджувати статус ВПО через бюрократичні процедури і періодичні перевірки або з повторним переміщенням. Аналіз просторових особливостей ВПО у розрізі міст, міських рад та районів Східного регіону України дозволив виділити три категорії ВПО в залежності від їх розміщення у регіоні. Серед них: переважна більшість - ВПО пенсійного віку, які орієнтуються на фактор територіальної близькості, реєструються у найближчих до лінії розмежування районах, хоча більшість із них фактично проживає на непідконтрольній Україні території, та здійснюють періодичні поїздки через лінію розмежування; ВПО працездатного віку, які розміщуються переважно у містах з метою працевлаштування та доступу до якісних послуг; найбільш вразливі та соціально незахищені категорії ВПО, які проживають у місцях компактного проживання населення, однак їх меншість. Розглянуто вікову структуру ВПО, переважаючою віковою групою усіх областей Східного регіону $\epsilon$ пенсіонери. Визначено регіони із найвищою часткою пенсіонерів та надмірним демографічним навантаженням пенсіонів та дітей з числа ВПО на місцеве населення. Зокрема, у деяких районах Луганської області чисельність пенсіонерів ВПО майже вдвічі перевищує чисельність місцевого населення всіх вікових груп. Така ситуація потребує особливої уваги, оскільки надмірна концентрація пенсіонерів ВПО на цих територіях може призвести до глибокої демографічної кризи. Отже, проведений суспільно-географічний аналіз просторового розподілу ВПО у Східному регіоні України показує реальні масштаби вимушеного внутрішнього переміщення населення в регіоні, а аналіз вікової структури ВПО дозволяє визначити варіанти впливу вимушених міграцій на соціально-економічний розвиток приймаючих регіонів та виступає індикатором необхідності прийняття відповідних програм або рішень щодо покращення становища ВПО.

Ключові слова: вимушена міграція, внутрішнє переміщення населення, внутрішньо переміщені особи (ВПО), мігранти, Східна Україна, воєнний конфлікт, демографічне навантаження. 
Вступ. Воєнний конфлікт з 2014 р., погіршення воєнно-політичної ситуації на Донбасі, окупація частини території Донецької та Луганської областей, поділ їх на дві частини, одна з яких контролюється українським урядом, а інша - так званими владами «самопроголошених республік», вперше за часів незалежності України спричинили масові вимушені внутрішні переміщення населення та появу нової для нашої країни категорії мігрантів - внутрішньо переміщених осіб (ВПО). Однак, воєнний конфлікт на Донбасі, який став головною причиною вимушених міграцій в Україні з 2014 р., викликаний сукупністю передумов та чинників, які вплинули на його активізацію або безпосередньо призвели до вимушених переміщень (Libanova, Horbulin, \& Pyrozhkov, 2015). Серед головних передумов, на наш погляд, є тривалі процеси заселення Східної України, строкатий етнонаціональний та етнолінгвістичний склад населення, міграційна політика радянського уряду «залучення робітників» 3 різних перенаселених регіонів Радянського Союзу у XX столітті, формування особливого регіонального соціуму Донбасу, якому притаманні «радянські цінності», територіальна приналежність населення Донбасу до України, а ментальна - до Росії, значні зв'язки, у т.ч. і родинні, населення Донбасу з Росією. До новітніх чинників конфлікту, на наш погляд, належать: зміна вектору зовнішньої політики та економіки на європейський, розірвання усталених десятиліттями економічних відносин із Росією, неувага центральної української влади до вирішення соціально-економічних проблем Донбасу, специфіка політичної ситуації в країні, значний російський вплив на політичне та культурне життя Донбасу. Починаючи 2014 року вимушені міграції, спричинені воєнним конфліктом на Донбасі, супроводжуються безпековими, економічними, соціальними, психологічними, індивідуальними чинниками.

За даними Міністерства соціальної політики України станом на кінець березня 2020 року чисельність ВПО в Україні складає 1 млн 447 тис осіб (3,5 \% від загальної чисельності населення країни) (Ministry of Social Policy of Ukraine, 2020). У найбільш активні фази воєнного конфлікту на Донбасі їх кількість сягала 1,8 млн осіб. Східна Україна, де власне i почався воєнний конфлікт та виникли вимушені внутрішні переміщення населення, прийняла майже 2/3 усіх ВПО. Станом на 01.01.2019 р. на території Донецької, Луганської та Харківської областей проживає 64,85 \% від загальної чисельності ВПО в Україні, а зазначені області займають відповідно перше, друге та четверте (після м. Києва) місця за їх чисельністю. У Донецькій та Луганській областях $\epsilon$ населені пункти та райони, у яких чисельність ВПО значно перевищує чисельність місцевого населення, що створює надмірне навантаження на ринок праці, об’єкти інфраструктури, органи місцевої влади тощо (Ministry of Social Policy of Ukraine, 2020).

Усе вищезазначене підтверджує важливість та актуальність проведення досліджень саме у Східній Україні, оскільки це регіон з найвищою в Україні часткою ВПО, проблеми переселенців все ще залишаються невирішеними, ВПО впливають на соціально-економічний розвиток регіонів та приймаючих громад, змінюють структурні особливості демографічної ситуації у регіоні. Тому комплексний просторово-часовий аналіз ВПО у розрізі міст, міських рад та районів Східної України дозволить виявити та проаналізувати сучасні масштаби вимушених міграцій, розглянути динамічні особливості, визначити територіальні диспропорції їх розміщення, що особливо актуально у контексті виявлення людського потенціалу ВПО, впливу їх на приймаючі громади та регіони, розробки регіональних стратегій щодо покращення соціально-економічного становища вимушених мігрантів тощо.

Аналіз останніх досліджень та публікацій. Дане дослідження спирається на теоретичні та практичні напрацювання вітчизняних авторів, присвячених міграційним процесам, зокрема вимушеним міграціям населення. Серед науковців, які займались даною проблематикою слід зазначити соціологів, економістів, демографів, суспільних географів, зокрема, В. Антонюк, Н. Гусєву, Е. Лібанову, О. Малиновську, О. Новікову, Л. Нємець, К. Сегіду, В. Смаль, С. Пугача та ін. Е. Лібанова, О. Новікова, С. Пирожков та ін. вивчали сучасні міграційні процеси в Україні у контексті глобальних викликів, вимушене переміщення з Автономної Республіки Крим та Донбасу та його наслідки (Libanova et al. 2015; Pyrozhkov et al., 2018). Співробітники Інституту економіки промисловості О. Новікова, О. Амоша, В. Антонюк приділяють велику увагу проблемам соціально-економічного розвитку Донбасу, причинам та наслідкам воєнного конфлікту, дослідженню людського потенціалу ВПО (Novikova, Amosha, \& Antoniuk, 2016).

Багато досліджень, присвячених вимушеним міграціям, проведено суспільними географами Харківського національного університету імені В. Н. Каразіна. Зокрема, Л. Нємець, К. Сегіда, Н. Гусєва, М. Логвинова та ін. досліджували просторово-часові особливості внутрішнього переміщення населення у Харківській області, а також фактори, які впливають на вибір переселенцями області як регіону для свого проживання, соціально-економічні, інституційні та психологічні проблеми ВПО, можливі шляхи їх успішного вирішення, питання інтеграції ВПО у приймаючі громади тощо (Niemets, Husieva, Lohvynova, Kandyba, \& Kliuchko, 2018; Niemets et al., 2019; Niemets, Husieva, Pohrebskyi, Bartosh, \& Lohvynova, 2019). Обрана методика суспільногеографічного дослідження внутрішнього переміщення населення спирається на праці К. Нємця, Л. Нємець (Niemets \& Niemets, 2014) та М. Логвинової (Lohvynova, 2019c). Однак, на сьогодні не достатньо вивченими залишаються питання просторового розміщення ВПО, людського потенціалу переселенців та їх впливу на соціально-економічний розвиток приймаючих регіонів, що потребує подальших суспільногеографічних досліджень. 
Теоретико-методологічні основи дослідження

Мета дослідження полягає у виявленні та обгрунтуванні просторово-часових особливостей вимушеного внутрішнього переміщення населення на Сході України з 2014 по 2019 рр. Ключовими питаннями даного дослідження виступають такі питання: Як змінилась чисельність ВПО на Сході України за період 2014-2019 рр.? Які адміністративнотериторіальні одиниці Східної України прийняли найбільше ВПО? Які чинники впливають на розміщення ВПО у Східному регіоні? Для пошуку конкретних відповідей на дані запитання та для досягнення мети дослідження нами поставлені наступні дослідницькі завдання: проаналізувати динаміку чисельності ВПО на Сході України за період 2014-2019 рр., виявити різкі підйоми та спади, пояснити їх причини; розглянути регіональні особливості розміщення ВПО у розрізі міст обласного значення, міських рад та районів Східної України; пояснити чинники надмірної концентрації ВПО у деяких адміністративно-територіальних одиницях; проаналізувати регіональні відмінності вікової структури ВПО.

Методика суспільно-географічного дослідження внутрішнього переміщення населення на Сході України базується на комплексі філософських, загальнонаукових та конкретнонаукових методів та низці міжгалузевих підходів. Оскільки внутрішнє переміщення населення $є$ невід'ємною складовою сучасних міграційних процесів України, у дослідженні використовувались такі підходи: географічний (розглядає внутрішнє переміщення населення у просторовому аспекті, забезпечує комплексність суспільно-географічного дослідження); системний (внутрішнє переміщення населення розглядається як велика, складна, відкрита, багаторівнева підсистема складної міграційної системи регіону); синергетичний (у дослідженні складових елементів міграційних процесів у загальній демографічній системі 3 позицій іï можливостей до еволюції i саморозвитку); історичний (для виявлення динамічних особливостей $\mathrm{BПО);} \mathrm{демографічний}$ (розглядає явище вимушеної міграції через призму демографічних показників: чисельності населення, статевовікової структури та відтворення населення); економічний (вплив ВПО на соціально-економічний розвиток регіонів) тощо (Niemets \& Niemets, 2014; Lohvynova, 2019c).

Методика дослідження включає наступні методи: математико-статистичний метод - для збору, обробки та аналізу первинних статистичних матеріалів щодо вимушених мігрантів; методи аналізу та синтезу - для виокремлення регіональних особливостей розміщення, враховуючи певні демографічні та економічні показники ВПО; метод узагальнення - для узагальнення наявних статистичних даних щодо ВПО; метод опису - для опису просторово-часових особливостей вимушених мігрантів; метод систематизації для систематизації отриманої інформації про об'єкт дослідження у вигляді системи даних; ретроспективний метод - для виявлення динамічних особливостей ВПО; графічний метод для візуалізації результатів дослідження, наочного відображення процесів і явищ 3 метою подальшого аналізу отриманої інформації у просторово-часовому континуумі; картографічний метод і картографічне моделювання - для картографування та візуалізації просторово-часових особливостей ВПО (Niemets \& Niemets, 2014; Lohvynova, 2019c; Niemets et al., 2019).

Дослідження базується на реальних статистичних даних, узагальнених Міністерством соціальної політики України, яке веде облік внутрішньо переміщених осіб за такими категоріями: кількість ВПО, кількість сімей ВПО, серед них: кількість дітей, осіб працездатного віку, пенсіонерів, осіб 3 інвалідністю. Статистичні дані у розрізі міст обласного значення, міських рад та районів одержано за допомогою запитів про доступ до публічної інформації до Донецької, Луганської та Харківської обласних державних адміністрацій та Харківської міської ради. Дані щодо кількості ВПО, які не змогли успішно інтегруватись у приймаючі громади та мешкають у місцях компактного проживання ВПО надало Міністерство з питань реінтеграції тимчасово окупованих територій України.

Результати дослідження та їх обговорення. За масштабами вимушених міграцій Східна Україна була та залишається регіоном із найбільшою чисельністю внутрішньо переміщених осіб, оскільки саме на Донбасі вперше за часів незалежності України, починаючи 32014 р. виникли вимушені міграції населення. Масштаби вимушеного внутрішнього переміщення населення змінювались в залежності від погіршення воєнно-політичної ситуації на Донбасі, дій уряду щодо забезпечення населення ВПО соціальними виплатами та обумовлені прагненням ВПО зберегти власне життя та свободу, а також соціально-економічними та культурно-ціннісними чинниками (Lohvynova, 2019a).

Починаючи 32014 року у Східній Україні відбулось декілька хвиль вимушеної міграції. В залежності від цього змінювалась чисельність ВПО. На початку воєнного конфлікту на Донбасі навесні 2014 р. вимушені переміщення населення ще не були такими масовими, більшість мігрантів, які покинули тимчасово окуповані території України вважали, що це ненадовго і мали наміри повернутись після завершення конфлікту. Вони шукали тимчасове житло у друзів, родичів чи знайомих та очікували стабілізації ситуації (Pyrozhkov et al., 2018; Lohvynova, 2020). Перші дані про ВПО зі Сходу України зафіксовані 31.10.2014 року. Тоді в Україні налічувалось 113 тис ВПО, переважно з Луганської області, 3 яких 16,2 \% розмістились у Донецькій області, 11,3 \% - у м. Києві, 10,0 \% - у Дніпропетровській області, 9,5 \% - у Харківській області. Лише 0,6 \% від усіх ВПО України зареєстровано у Луганській області. До кінця року чисельність ВПО рекордно збільшилась у Луганській області 3684 осіб до 85581 особи (на 12411,8 \%), у Донецькій області 3 18355 осіб до 300265 осіб (на 1539,9 \%), у Харківській області з 10795 осіб до 106281 особи (на 884,5 \%) (рис. 1). Загалом по Україні станом на 05.01.2015 року 
зареєстровано 842439 ВПО (Ministry of Social Policy of Ukraine, 2020). Це люди, які безпосередньо постраждали від бойових дій - зазнали загрози власного життя чи життя рідних і близьких людей, зіткнулись 3 руйнуванням житла, втратили майно та роботу (Lohvynova, 2019a; Lohvynova, 2020).

Найбільшою чисельність ВПО в Україні з часу їх появи була у середині 2016 року - 1785740 осіб. Східний регіон України тоді прийняв 67,0% від їх загальної чисельності, зокрема, Донецька область - 727993 особи, Луганська область - 273632 особи, Харківська область - 190324 особи (Ministry of Social Policy of Ukraine, 2020). На збільшення чисельності ВПО вплинули рішення так званих «ДНР» та «ЛНР» щодо прийняття усіма жителями цих «республік» їх громадянства. Це поставило населення тимчасово окупованих територій України перед вибором: або прийняти громадянство «самопроголошених республік», або переселитись на підконтрольну українському уряду територію та отримати статус ВПО (Niemets et al., 2019). Ретельно обдумуючи рішення про міграцію, переселенці вже обирали регіони 3 високим рівнем соціально-економічного розвитку та, як правило, не планували повертатися назад. Суттєвим приводом до вимушеної міграції населення у цей період стала активізація бойових дій в районі Мар'їнки та Авдіївки у січні-лютому 2016 р., що спричинило реальну загрозу життю та здоров'ю населення.

Починаючи з 2017 року чисельність ВПО в регіоні стрімко зменшується, що говорить про успішну інтеграцію вимушених мігрантів у приймаючі спільноти або небажання підтверджувати статус ВПО, спричинене бюрократичними процедурами та періодичними перевірками (Niemets et al., 2018; Niemets et al., 2019). Також існують випадки повторного вимушеного переміщення у інші регіони України або за кордон частини ВПО, яка не змогла успішно інтегруватися у попередньому місці переміщення. Станом на 01.01.2019 р. частка ВПО Донецької, Луганської та Харківської областей від загальної чисельності ВПО в Україні становить

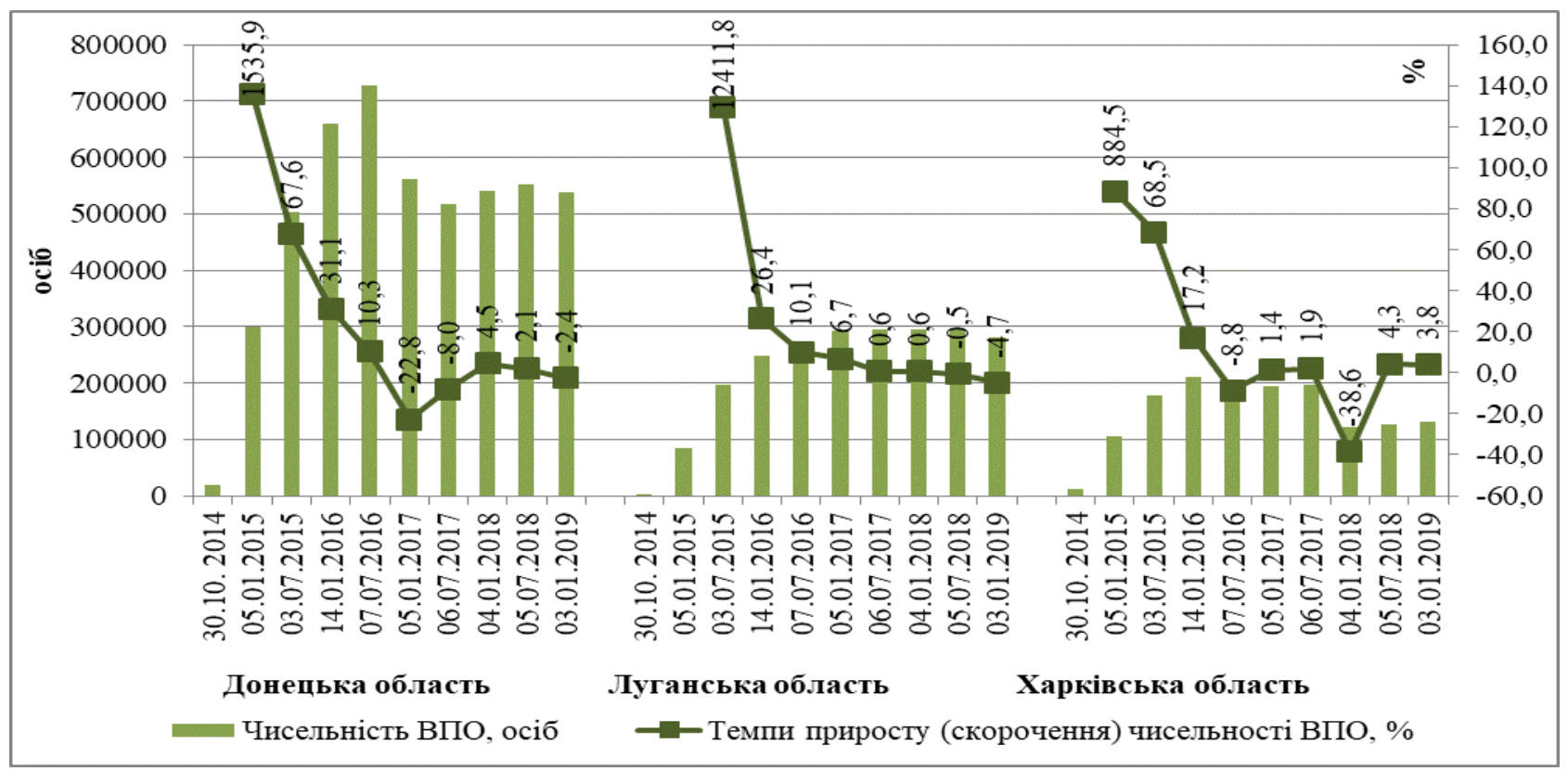

Рис. 1. Динаміка чисельності ВПО у Донецькій, Луганській та Харківській областях за 2014-2019 рр. (підраховано та побудовано автором за даними Міністерства соціальної політики України, 2020)

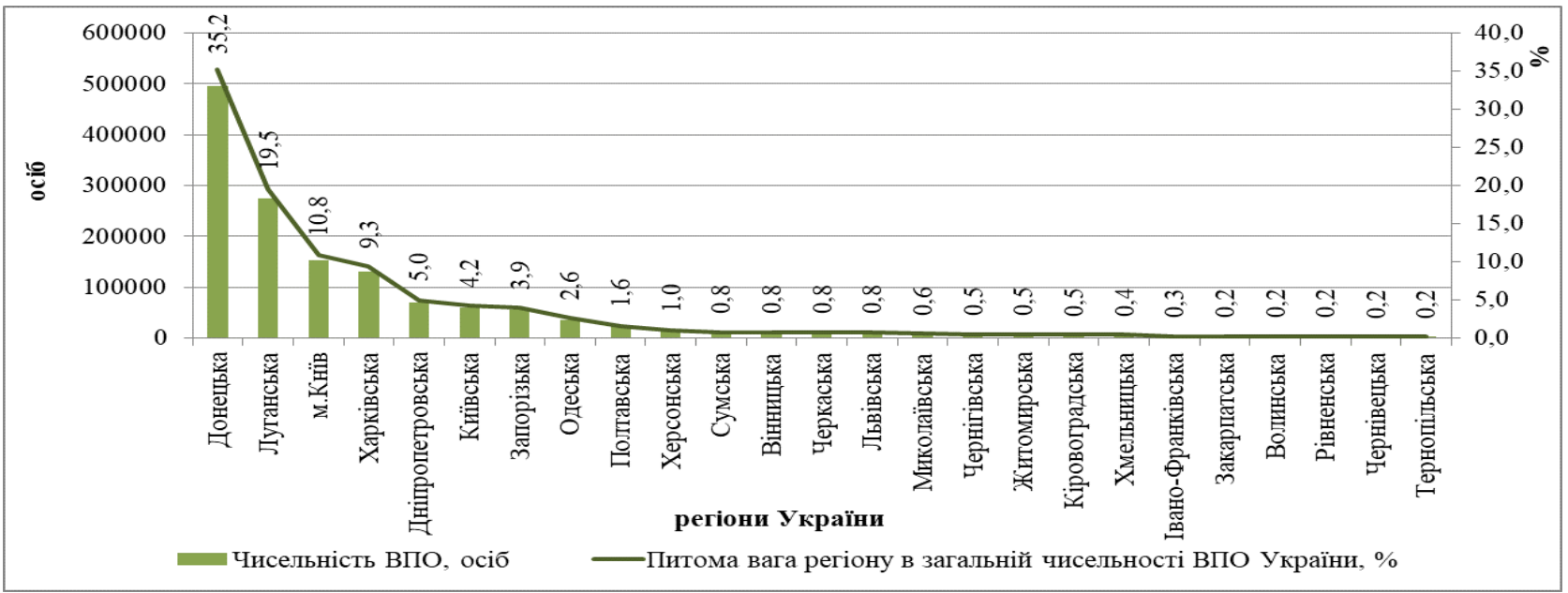

Рис. 2. Розподіл регіонів України за чисельністю та питомою вагою ВПО станом на 01.01.2019 року (підраховано та побудовано автором за даними Міністерства соціальної політики України, 2020) 
64,85 \%, а зазначені області займають відповідно перше, друге та четверте (після м. Києва) місця за їх чисельністю (рис. 2) (Ministry of Social Policy of Ukraine, 2020).

Внутрішньо переміщені особи по території Східного регіону України розміщені вкрай нерівномірно. Щодо факторів, які впливають на вибір ВПО адміністративно-територіальної одиниці у межах Східного регіону для розміщення, їх можна поділити на декілька категорій.

Перша категорія - $\mathrm{BПО,} \mathrm{які} \mathrm{зіткнулись} \mathrm{із}$ пошкодженням або втратою житла, майна, втратили роботу в результаті погіршення воєнно-політичної ситуації на Донбасі, загострення воєнних дій, обдумано прийняли рішення щодо переміщення без можливостей повернення на попереднє місце проживання (Lohvynova, 2020). Такі ВПО обирали для розміщення здебільшого обласні центри, міста обласного та районного значення із розвинутими ринками праці, промисловою спеціалізацією, яка відповідає кваліфікації населення Донбасу, необхідною інфраструктурою тощо. Серед представників цієї категорії ВПО висока частка працездатного населення (Lohvynova, 2019b).

Друга категорія ВПО, серед представників якої переважно пенсіонери та особи, які отримують соціальні виплати, обрала шлях проживання по обидва боки лінії розмежування, тому сконцентрована у прилеглих до лінії розмежування населених пунктах. Переселенці, у яких на тимчасово окупованій території залишились родичі та близькі люди, які потребують догляду, майно та присадибні ділянки, змінили місце проживання та зареєструвались як ВПО, хоча фактично мешкають на непідконтрольній Україні території та не вважаються внутрішньо переміщеними особами. У 2015 році в Україні внаслідок прийняття низки законів та постанов щодо регулювання суспільних відносин, пов'язаних із внутрішнім переміщенням осіб з окремих районів Донецької та Луганської області, непідконтрольних Україні внаслідок воєнного конфлікту на Донбасі виникло явище т.з. «пенсійного туризму». Згідно 3 постановою № 595 пенсіонери опинились перед вибором: покинути тимчасово окуповані території України та отримати статус внутрішньо переміщеної особи, або залишатись на непідконтрольній Україною території без гарантованих державою соціальних виплат на невизначений час. Обравши перший варіант, перед пенсіонерами постали проблеми забезпеченості житлом, продуктами харчування та медикаментами, оскільки єдиними джерелом їх існування залишилась мізерна пенсія. Тому практикою для сотень тисяч людей, переважно пенсійного віку, та єдиною можливістю отримання належних їм та гарантованих державою виплат, стала їх реєстрація як ВПО, але де-факто вони проживають на тимчасово непідконтрольній території України та регулярно переміщуються через лінію зіткнення 3 метою отримання пенсії та інших соціальних виплат (Niemets et al., 2018; Niemets et al., 2019; Niemets et al., 2019).
Третя категорія ВПО - особи, які проживають у місцях компактного проживання. Як правило, це найбільш вразливі категорії - багатодітні родини, матері-одиначки, особи з інвалідністю, пенсіонери, які втратили власне житлота найбільш потребують державної допомоги. Частка населення даної категорії становить 0,33 \% (3109 осіб) від загальної чисельності ВПО в регіоні (Ministry of Reintegration of Temporarily Occupied Territories of Ukraine, 2020).

Станом на 01.01.2019 p. 35,2 \% (538 751 особа) усіх ВПО України проживають на території Донецької області, 19,5 \% (280549 осіб) - у Луганській області та 9,3 \% (131564 особи) - у Харківській області. Питома вага ВПО Донецької області у Східному регіоні України - 56,7 \%, Луганської області - 29,5%, Харківської області - 13,8 \% (Ministry of Social Policy of Ukraine, 2020). Для Східного регіону характерна надмірна концентрація ВПО у містах, що дає переселенцям доступ до ринків праці та можливість забезпечення якісними соціальними послугами.

У регіональному аспекті найбільша питома вага ВПО серед їх загальної чисельності в регіоні у містах Маріуполь - 10,5 \% (99967 осіб), Харків 9,2 \% (87887 осіб), Сєвєродонецьк - 5,4 \% (51189 осіб), Бахмут - 4,3 \% (41308 осіб), Слов'янськ - 3,9\% (37051 особа). Серед районів найбільша частка ВПО у Волноваському районі Донецької області - 5,3 \% (50719 осіб) та центральних районах Луганської області - Біловодському - 3,9 \% (36898 осіб) та Старобільському-3,1 \% (29330 осіб) (Donetsk Regional State Administration, 2020; Luhansk Regional State Administration, 2020). У Харківській області 66,8 \% усіх ВПО розміщені в обласному центрі місті Харкові (рис. 3) (Kharkiv Regional State Administration, 2020).

ВПО чинять неабияке навантаження на приймаючі їх громади та регіони, а у деяких населених пунктах Східної України їх чисельність майже вдвічі перевищує чисельність місцевого населення. Так, наприклад, у Марківському районі Луганської області на 1000 осіб місцевого населення проживає 1969 осіб ВПО, у Біловодському районі - 1594 особи, у Міловському районі - 1115 осіб (Luhansk Regional State Administration, 2020). Високе навантаження ВПО на 1000 осіб місцевого населення (понад 500 осіб) і у Донецькій області м. Бахмут, Лиманській міській раді, м. Новогродівка, Волноваському, Мангушському, Нікольському, Слов'янському районах (Donetsk Regional State Administration, 2020). Така кількість зареєстрованих ВПО створює надмірне навантаження на локальні ринки праці, соціальну інфраструктуру, державні органи влади та органи місцевого самоврядування (Novikova et al., 2016; Niemets et al., 2019).

Основною віковою групою ВПО Східного регіону України є пенсіонери. У Луганській області їх частка становить 77,9 \% від загальної чисельності ВПО в регіоні, у Донецькій області - 63,1%, у Харківській області - 41,9 \%. Така висока частка пенсіонерів серед ВПО регіону обумовлена прив'язкою виплати пенсій до статусу ВПО та явищем т.з. «пенсійного туризму» (Niemets et al., 2019). У регіональному аспекті найбільша частка пенсіонерів (понад 80 \%) 
серед населення Біловодського, Кремінського, Марківського, Міловського районів Луганської області та Слов'янського, Костянтинівського районів Донецької області. Лідером серед усіх адміністративно-територіальних одиниць Східної України за часткою пенсіонерів серед ВПО $є$ Барвінківський район Харківської області - 89,3 \% (рис. 4) (Donetsk Regional State Administration, 2020; Luhansk Regional State Administration, 2020; Kharkiv Regional State Administration, 2020).

Висока частка пенсіонерів у даних районах обумовлена їх близькістю до лінії розмежування, спрощеними процедурами реєстрації місця проживання для отримання статусу ВПО у цих районах та непривабливістю їх для працездатного населення (Niemets et al., 2018). Це також призводить до надмірного демографічного навантаження пенсіонерів та дітей з числа ВПО на працездатне населення, яке на 1000 осіб місцевого населення у Марківському районі Луганської області становить 2647 осіб, Біловодському районі - 2126 осіб та Міловському районі - 1115 осіб відповідно. Високе демографічне навантаження ВПО пенсіонерів та дітей на 1000 осіб місцевого населення (понад 500 осіб) у м. Бахмут, Лиман, Новогродівка, Волноваському, Мангушському, Нікольському, Слов'янському районах Донецької області та Старобільському районі Луганської області. У Харківській області найбільше навантаження ВПО у Ізюмському (325 осіб), Борівському (186 осіб), Барвінківському (105 осіб) районах та у м. Ізюм (146 осіб), що створює додаткове навантаження на дитячі садочки, школи, конкуренцію за робочі місця серед працюючих пенсіонерів, значні черги у органах соціального захисту населення, об'єктах інфраструктури тощо (Donetsk Regional State Administration, 2020; Luhansk Regional State Administration, 2020; Kharkiv Regional State Administration, 2020).

\section{Висновки}

Отже, на Східний регіон України, який $\epsilon$ лідером 3 розміщення внутрішньо переміщених осіб в Україні, припадає 64,85 \% від їх загальної чисельності в Україні. Безперечно, найбільша кількість ВПО сконцентрована у Донецькій області. Луганська та Харківська області займають

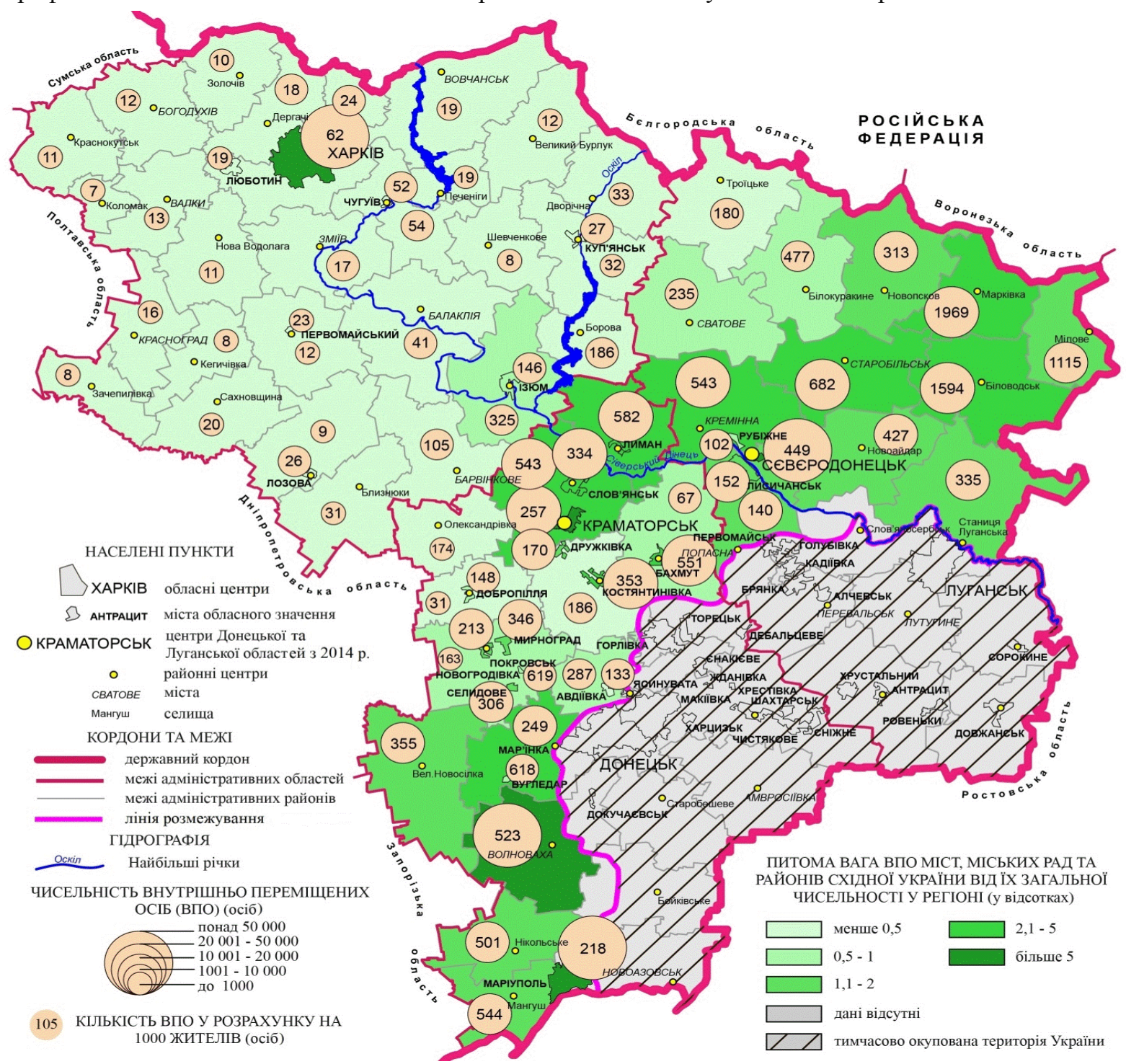

Рис. 3. Просторові особливості ВПО у Східному регіоні України станом на 01.01.2019 року (підраховано та побудовано автором за даними офіційних вебсайтів Донецької, Луганської та Харківської обласних державних адміністрацій) 
відповідно друге та четверте місця за чисельністю ВПО в Україні. Динаміка чисельності ВПО в регіоні вказує на спад, що обумовлено, на наш погляд, успішною інтеграцією деяких ВПО у приймаючі громади, небажанням підтверджувати статус ВПО через бюрократичні перепони і періодичні перевірки та повторним переміщенням частини ВПО у інші регіони України або закордон. Це призводить до зменшення частки працездатного населення у віковій структурі ВПО, частка ж пенсіонерів у деяких адміністративно-територіальних одиницях або дещо збільшується, або залишається незмінною. Загалом у віковій структурі населення усіх міст, міських рад та районів Східного регіону, окрім м. Харкова, переважають пенсіонери, а у Луганській області їх частка становить 77,5 \%. У трьох районах Луганщини (Біловодському, Марківському, Міловському) чисельність пенсіонерів ВПО перевищує або майже дорівнює чисельності місцевого населення усіх вікових груп. Така ситуація потребує уваги не лише місцевих, а й державних органів влади, оскільки така надмірна концентрація пенсіонерів ВПО на цих територіях може суттєво поглибити демографічну кризу.

Регіональні особливості розміщення ВПО вказують на нерівномірну їх концентрацію: як правило, орієнтуючись на чинник територіальної близькості до тимчасово непідконтрольних українському уряду територій, ВПО, які мають родичів чи майно на окупованій території реєструються ближче до лінії розмежування та періодично перетинають iii 3 метою догляду за родичами, отримання пенсії, соціальних виплат тощо. ВПО, яких ніщо не тримає на тимчасово окупованій території обрали для свого розміщення великі міста, міста обласного та районного значення із розвинутими ринками праці та інфраструктурою. Таке розміщення ВПО чинить навантаження на локальні ринки праці, але, враховуючи високий працересурсний, культурно-освітній, інноваційний потенціал працездатного населення ВПО, це можна перетворити на перевагу, що полягає у можливості соціально-економічного розвитку регіонів за рахунок ВПО.

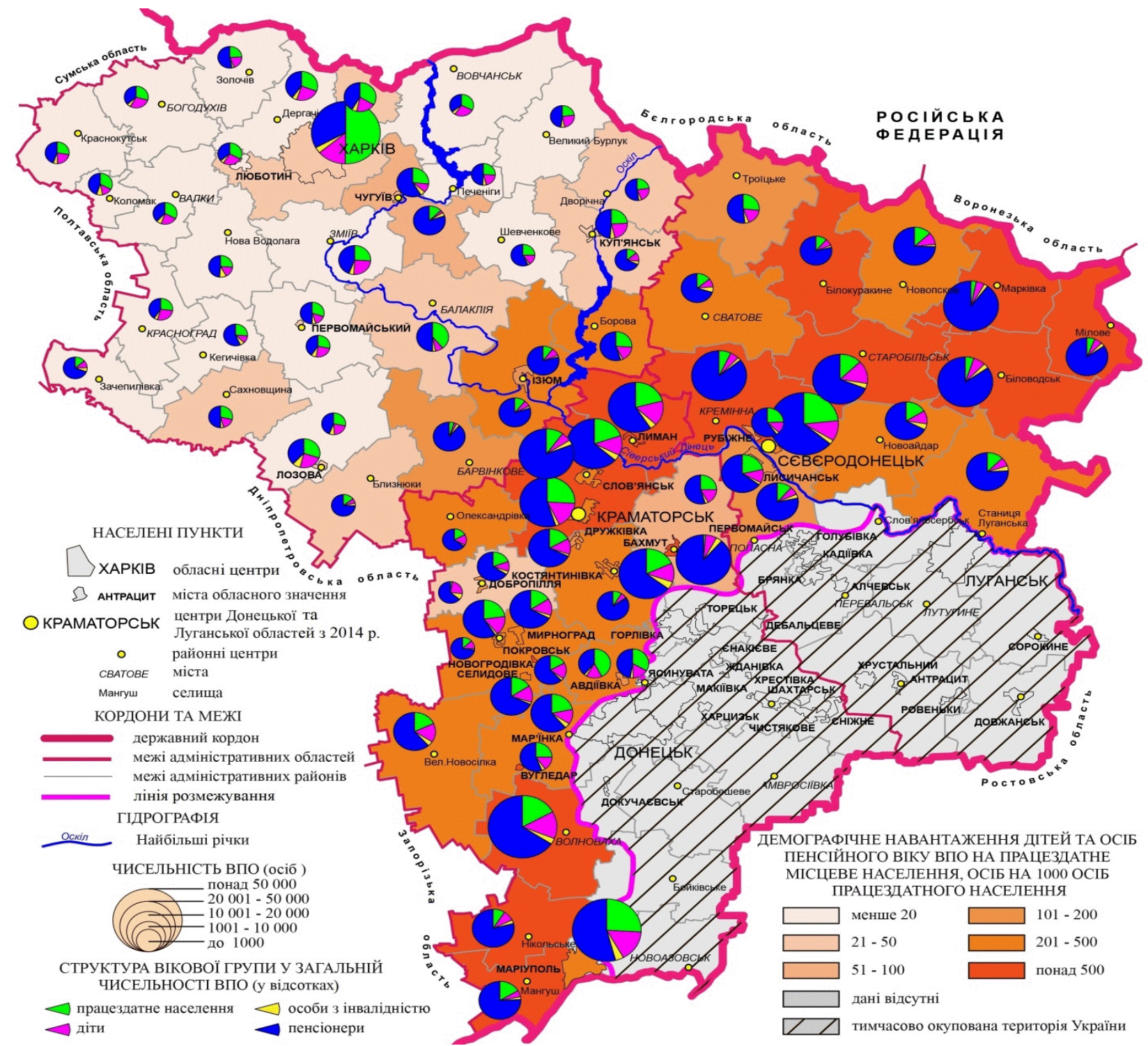

Рис. 4. Вікова структура ВПО Східної України станом на 01.01.2019 року

(підраховано та побудовано автором за даними офіційних вебсайтів Донецької, Луганської та Харківської обласних державних адміністрацій) 


\section{References:}

1. Donetsk Regional State Administration (2020). Official website. Access mode: https://dn.gov.ua/ua.

2. Kharkiv Regional State Administration (2020). Official website. Access mode: https://kharkivoda.gov.ua.

3. Libanova, E. M., Horbulin, V. P., \& Pyrozhkov, S. I. (2015). The integration policy of Ukrainian society in the context of challenges and threats of events in the Donbas (national report). Kyiv: NAS of Ukraine. [In Ukrainian]. [Лібанова Е. М. Політика інтеграції українського суспільства в контексті викликів та загроз подій на Донбасі (національна доповідь) / Е. М. Лібанова, В. П. Горбулін, С. І. Пирожков та ін. [за ред. Е. М. Лібанової]. К.: НАН України, 2015. 363 с.]

4. Lohvynova, M. O. (2019a). Forced migrations in Ukraine: a dynamic aspect. In A. O. Kornus (ed.), Fourth Sumy scientific geographical readings (Sumy, Sumy State Pedagogical University and Sumy Department of the Ukrainian Geographical Society) (pp. 147-153). [In Ukrainian]. [Логвинова М. О. Вимушені міграції в Україні: динамічний аспект // Четверті Сумські наукові географічні читання: збірник матеріалів Всеукраїнської наукової конференції, 11-13 жовтня 2019 р. м. Суми. / СумДПУ імені А. С. Макаренка, Сумський відділ Українського географічного товариства; [упорядник Корнус А. О.]. Суми, 2019. С. 147-153.]

5. Lohvynova, M. O. (2019b). On the issue of placement factors for internally displaced persons from the East of Ukraine]. Scientific Bulletin of Kherson State University. Series Geographical Sciences, 10, 27-33. [In Ukrainian]. [Логвинова М. О. До питання про чинники розміщення внутрішньо переміщених осіб зі Сходу України [Текст] / М. О. Логвинова // Науковий вісник Херсонського державного університету. Серія «Географічні науки». 2019. № 10. C. 27-33.]

6. Lohvynova, M. (2019c). To the methodology of socio-geographical research of the internal displacement of the population. Human Geography Journal, 27, 20-27.

7. Lohvynova, M. (2020). Stages of forced internal displacement of the population from East Ukraine. In Yu. M. Barskyi, S. O. Puhach (eds.), Socio-geographical factors of regional development. Materials of the IV International Scientific and Practical Internet Conference (pp. 12-15). Lutsk. [Lohvynova M. Stages of forced internal displacement of the population from East Ukraine // Суспільно-географічні чинники розвитку регіонів: матеріали IV Міжнар. наук.-практ. Інтернет-конференції, 9-10 квітня 2020 р. м. Луцьк / за ред. Ю. М. Барського, С. О. Пугача. Луцьк, 2020. С. 12-15.]

8. Luhansk Regional State Administration (2020). Official website. Access mode: http://loga.gov.ua.

9. Ministry of Reintegration of Temporarily Occupied Territories of Ukraine (2020). Official website. Access mode: https://mtot.gov.ua/ua/informacija-schodo-misc-kompaktnogo-projivannja-mkp-vnutrishno-peremischenihosib.

10. Ministry of Social Policy of Ukraine (2020). Official website. Electronic source. Access mode: http://www. msp.gov.ua/timeline/Vnutrishno-peremishcheni-osobi.html.

11. Niemets, L. M., Husieva, N. V., Lohvynova, M. O., Kandyba, Yu. I., \& Kliuchko, L. V. (2018). Forced internal migration in the Kharkiv region: structural-dynamic and regional features. HumanGeographyJournal, 25, 81-97. [In Ukrainian]. [Нємець Л. М., Гусєва Н. В., Логвинова М. О., Кандиба Ю. І., Ключко Л. В. Вимушені внутрішні міграції в Харківській області: структурно-динамічні та регіональні особливості // Часопис соціальноекономічної географії. 2018. № 25. С. 81-97.]

12. Niemets, L., Husieva, N., Pohrebskyi, T., Bartosh, O., \& Lohvynova, M. (2019). Integration of internally displaced persons of Ukraine: realities, problems, perspectives. Visnyk of V. N. Karazin Kharkiv National University, series "Geology. Geography. Ecology", 51, 140-157.

13. Niemets, L., Husieva, N., Sehida, K., Kraynukov, O., Lohvynova, M., Suptelo, O. (2019). Forced internal displacement in Ukraine: realities, socio-economic problems, perspectives. In Vision 2020: Sustainable Economic Development and Application of Innovation Management from Regional expansion to Global Growth. The International Business Information Management Conference (33nd IBIMA) (Granada, Spain, 10-11 April, 2019) (pp. 3062-3081).

14. Niemets, K. A., \& Niemets, L. M. (2014). Theory and methodology of geographical science: spatial analysis methods: a training manual. V. N. Karazin Kharkiv National University. [In Ukrainian]. [Нємець К. A., Нємець Л. М. Теорія і методологія географічної науки: методи просторового аналізу: навчально-методичний посібник. Харків: ХНУ імені В. Н. Каразіна, 2014. 172 с.]

15. Novikova, O. F., Amosha, V. P., \& Antoniuk, V. P. (2016). Internally Displaced Persons: from overcoming obstacles to success strategies: monograph. Kyiv: NAS of Ukraine. [In Ukrainian]. [Внутрішньо переміщені особи: від подолання перешкод до стратегії успіху: монографія / О. Ф. Новікова, О. І. Амоша, В. П. Антонюк та ін. К.: НАН України, Ін-т економіки пром-сті, 2016. 448 с.]

16. Pyrozhkov, S. I., Libanova, E. M., Novikova, O. F., Skrypniuk, O. V., Ustymenko, V. A., Khamitov, N. V., \& Shulha, M. O. (eds.) (2018). Ukrainian society: the migration dimension: national report. Kyiv: Ptoukha Instutute for Demography and Social Studies. [In Ukrainian]. [Українське суспільство: міграційний вимір: нац. доповідь / Інститут демографії та соціальних досліджень ім. М. В. Птухи НАН України. К., 2018. 396 с.] 